\title{
El ser sexual en la poesía de Eunice Odio
}

\author{
Anthony J. Robb
}

Rowan University, Estados Unidos

\section{RESUMEN}

Describe y analiza los temas y procedimientos discursivos de siete extensos poemas de Eunice Odio, y se detiene en dos aspectos: lo sexual en cuanto asociado al cuerpo como objeto poético, y la condición de la conciencia existencial en la naturaleza; así, el discurso erótico en la poesía pasa a ser un proceso de trasgresión. Odio experimenta con tópicos, con alusiones intertextuales y con temas recurrentes que apartan su obra poética de la poesía convencional amorosa, y la muestran como una notable manifestación vanguardista.

\section{Abstract}

This article describes and analyzes the discourse techniques of seven long poems by Eunice Odio, and emphasizes two particular aspects: sexuality and its relation with the body as a poetic object, and the condition of existential awareness in nature. Thus the erotic discourse in this poetry becomes a process of transgression. Odio experiments with topics, intertextual allusions and recurring themes which set her poems apart from conventional love poetry, and identify her with an outstanding avant-guard perspective.

A diferencia de otros enfoques posibles que conciernen la sexualidad y el erotismo en la obra de Eunice Odio, en este estudio se analizarán sólo aquellos poemas que sugieren o aluden a la sexualidad 
del ser humano en un contexto ajeno a la comunicación (léase "comunión") o falta de comunicación entre amantes. En particular, se explorarán los poemas que se refieren a la sexualidad en los siguientes dos aspectos: primero, aquellos donde el lenguaje y las imágenes hacen referencia a los órganos sexuales y las áreas genitales del objeto poético o también de la voz poética, y segundo, aquellos donde la sexualidad está relacionada con la pubertad, la reproducción y la esterilidad. Los poemas escogidos para esta sección oscilan entre temas abiertamente sexuales, pero integrales al vivir diario del ser humano y su relación con la sociedad (por ejemplo, una hija en edad para casarse) y, por otra parte, temas que han sido relegados a los murmullos de los clubes de caballeros (por ejemplo, el tema de la prostitución). Para plasmar estos conceptos poéticos, el lenguaje al que recurre la poeta también oscila en su matización erótica: desde lo sensual y sugestivo hasta la clara denotación de la palabra.

Sin lugar a dudas, la sexualidad es el catalizador que impulsa la dialéctica entre el cuerpo de uno y la conciencia del mismo. Hablar de la sexualidad o sugerirla poéticamente en espacios públicos abre otro diálogo entre el poeta y el pueblo, aunque a veces, dicha articulación resulta estridente o repulsiva, y muy a menudo sacude las bases de la tradición poética y las de la sociedad en general. En este sentido, Eunice Odio, como sus precursores líricos (Whitman, Mistral y las otras voces posmodernistas hispanoamericanas), desempeña una labor fundamental en la revitalización poética en sus respectivas épocas. La selección de poemas reunidos aquí plasma temas e imágenes no tradicionales y considerados anteriormente tabúes, como explica Alfonso Chase al hablar del "orgasmo textual" en la introducción a su antología El amor en la poesía costarricense. Dice que Odio, entre otros escritores de la vanguardia,

convierte en carne real, humana e insatisfecha, a la palabra, buscando por medio del lenguaje, no sólo la afirmación de un estilo, sino un ejercicio dialéctico (mi énfasis) de análisis de 
nuevos valores culturales, que traen a nuestra literatura un cambio, un definitivo escalofrío, un horror nuevo y maravilloso, un orgasmo textual que transforma, para siempre, el modo de ser y escribir en Costa Rical.

Díez Borque hace una fina observación con respecto a la poesía erótica contemporánea:

Es el carácter absoluto y enérgico de eros, limitado en posibilidad de situaciones pero rico en matices, [...]. El que estos sentimientos puedan ser sublimados y el que en la práctica social de la vida diaria existan obligaciones inhibitorias no es sino el resultado de necesidades impuestas por el orden social establecido y es una prueba del papel totalizador de los principios del eros que en líneas generales, no tanto en algunas particularizaciones, expuso Freud ${ }^{2}$.

Lo que dice Díez Borque reafirma la aseveración de Chase acerca de la poesía erótica costarricense como manifestación de los aires de la vanguardia. Odio sublima estos temas y lenguaje tabúes, a los que aludo en este capítulo, para lograr precisamente esta dialógica. Como comenta Myriam Díaz-Diocaretz en su artículo "I will be a scandal in your boat': Women poets and the tradition", "writing is not to be kept behind closed doors - unless the ruling political system gives us no choice - that poetry is not the exclusive art by and for an elite, but that the poet is part of the world, and that world belongs in our vision"3. Odio no es la excepción: abre las puertas del clóset metafórico y comparte estos temas sociales y humanos con el prójimo. Veamos cómo sucede esto en la obra de esa escritora.

1. Alfonso Chase, El amor en la poesía costarricense (San José: Editorial Costa Rica, 2000) xviii.

2. José María Díez Borque, ed. Introducción Poesía erótica: Siglos XVI-XX (Madrid: Siro, 1977) 43-44.

3. Myriam Díaz-Diocaretz, "I Will be a Scandal in Your Boat": Women Poets and the Tradition», Knives and Angels: Women Writers in Latin America (Londres: Zed, 1990), 87. 


\section{“Tríptico de la doncella"4}

Este poema parte del Cantar de Cantares del rey Salomón ${ }^{5}$. La poeta se apropia del texto literalmente y reproduce los dos versículos en la primera estrofa, la cual plantea el tema o enigma que se va a desarrollar en el poema. El concepto poético es la inminente transición física de la "pequeña" hermana prepubescente en mujer sexual, lo que a la vez representa un reto para su familia. Aunque Odio se nutre del tema del canto bíblico, lo desarrolla de forma completamente diferente. Como el título "tríptico" alude, el poema se estructura en tres cantos o "círculos", cada uno con su propio subtítulo. La estructura en sí obedece hasta cierto punto a una obra de teatro clásica. Aparecen en el poema acotaciones y estructuras dialógicas que se asemejan a un parlamento. La inclusión de un coro también le da un toque dramático al poema. La primera estrofa plantea la idea central: los "esposos" tienen una "pequeña hermana" sin pechos y se preguntan entre sí qué deben hacer. La primera estrofa es literalmente el texto bíblico y sirve como idea que rige todo el poema ${ }^{6}$. El Círculo Uno: HABLAN PARA Sí LOS ESPOSOS compone dos estrofas en las cuales los amados (uno de los dos es hermano o hermana de la niña) manifiestan su preocupación por ella. El Círculo Dos: LA NIÑA; EL PASTOR; H. CORO; LOS ESPOSOS compone seis parlamentos en los cuales los interesados reiteran el problema y sólo se enfocan en él. El Círculo Tres: I.OS ESPOSOS HACEN LA DEFENSA DE SU HERMANA Y LA OFRECEN COmpone cinco estrofas en las que los amantes ven más allá del problema, se dan cuenta de lo positivo que puede significar este efímero retardo en el desarrollo de su hermana y toman la decisión de actuar de acuerdo con las circunstancias, hecho que se remite conceptualmente a la primera

4. Se publicó en la revista La Pajarita de Papel, órgano del PEN Club de Honduras, $n^{\circ} 3$ (mayo-julio 1949) 61-63.

5. Capítulo 8, versículos 8-9, Biblia, ed. Reina Valera.

6. El "tríptico" se enfoca en el cuerpo prepubescente de la niña y más específicamente de su falta de pechos; de hecho, todas las estrof as señalan con claridad este dato. Este aspecto visible y exterior de la niña constituye el ímpetu poético. 
estrofa bíblica. Así, la primera estrofa y la última del tríptico encierran entre sí toda la acción que, más que "acción linear", ha sido meditación, evaluación, diálogo y decisión.

En su artículo sobre el Cantar de Cantares titulado "Beauty and the Enigma" ", Francis Landy comenta que existen dos ambigüedades: la voz poética, y más enigma que ambigüedad, las metáforas encontradas en el Canto 8: 8-10. En lo que concierne al primer caso, Landy explica que la voz puede ser la de los hermanos, las hermanas o de la amada misma, pero opina que los primeros dos se pueden excluir por problemas de estética y autoridad textuales ${ }^{8}$. En su poema, Odio ha sugerido que la niña es hermana de uno de los amados. En lo que se refiere al segundo caso, el enigma, cuyo enfoque es el tema principal del artículo de Landy, se presenta un problema para la hermenéutica de las imágenes descritas en los versículos señalados. Veamos la primera estrofa del poema odiano:

Tenemos una pequeña hermana

Que no tiene pechos.

¿Qué haremos a nuestra hermana

cuando de ella se hablare?

Si ella es muro,

Edificaremos sobre él un palacio de plata;

Y si fuera puerta

La guarneceremos con tablas de cedro (1-8).

7. En Harold Bloom, The Song of Songs (Nueva York: Chelsea House, 1988) 101.

8. Cita Landy: "La primera ambigüedad concierne al hablante, que puede ser los hermanos de 1: 5-6, hermana, o la Amada misma. Yo considero que es el caso de la última, puesto que los otros puntos de vista requerirían la introducción de nuevos persona jes sin la autoridad textual, lo que constituye un mal procedimiento crítico. Aun más, requiere la suposición de un flashback o la vista mala para tomarse en cuenta respecto a la discrepancia entre la no-existencia de los senos, así visto por los "hermanos", y su pleno desarrollo, así declarado por la Amada [...] Mi perspectiva simplemente es que la Amada habla como miembro de su familia, acerca de su hermanita quien está madurando físicamente", 101 (traducción mía). 
Landy señala que el enigma es explícito y que el texto contempla dos futuros hipotéticos: que ella sea "muro" o "puerta": "They ure thus either adversative and / or complementary" (101). Añade lo siguiente:

That there is some opposition is evident from $8: 10$, in which the assertion "I am a wall" explains the Beloved's success. What remains unclear, however, is whether "wall" and "door" are two kinds of beauty or character, both of which are of value, or whether they are contrasted. In the latter case, if the wall wins the Lover's favour and is crowned with silver, the door would correspondingly be unattractive ${ }^{9}$.

La autora del artículo of rece varias interpretaciones para diluidar estos dos valores en términos conceptuales de la belleza ${ }^{10}$. Para I presente estudio, analizaré, sin embargo, sólo las dos posibilidades jue parecen confirmar la interpretación de Odio, ya que la metáfora lel muro y la puerta se repite como símbolo en varios de sus otros wemas y connota el mismo significado como ya se ha podido apreiar en capítulos anteriores.

La voz lírica presenta el problema actual de que la hermanita stá creciendo y aún no ha desarrollado sus pechos. Una vez expresao el concepto, el hablante presenta las dos situaciones hipotéticas ue aluden al día en que el amado va a venir a pedirles la mano de la ermanita ("cuando de ella se hablare", 4).

En aquel día, ellos se preguntan retóricamente cómo será la ermanita: "muro" o "puerta". Debo aclarar que a través del poema I interesada no habla y constituye más bien el enfoque u objeto de

Landy, 101.

1. Landy cita otra posible interpretación: "Los críticos mayores vieron en esto una clara oposición de la virtud: el muro es la mujer inexpugnable y la puerta se abre a todos los que llegan. Tur-Sinai, seguido por Gordis y otros, comentan que "muro" y "puerta" son paralelismos sintéticos tradicionales; como el muro, la puerta normalmente se encuentra trancada, y por consiguiente, ellos creen que ambos expresan una reserva casta", 101-102 (traducción mía). 
contemplación de una sociedad patriarcal y sus correspondientes valores sobre la virginidad. Si la hermana es "muro", los esposos la premiarían por su virtuosidad y le construirán un "palacio de plata". Esta imagen parece sugerir que la hermana es digna de tal adorno valioso; por otra parte, resulta antitética porque connota no sólo adorno sino también fortificación. De ser puerta, se sugiere que la hermana es alevosa y podría sucumbir a posibles avances amorosos; en tal caso, "la guarnecerán con tablas de cedro". En un nivel superficial, los amantes parecen sugerir que protegerán la vulnerabilidad de la "puerta", es decir, la vagina o virginidad de la hermana. Por otra parte, esto podría sugerir que, como palacio de plata o fortificación, las tablas de cedro la adornarán además de protegerla. Tanto la plata como el cedro son materiales valiosos y duraderos; desempeñan las dos funciones. De modo que muro o puerta, la hermana será adornada y protegida en esencia. Si esta es una exégesis viable, entonces lo que comenta Landy sobre el particular cobra sentido:

Silver is conspicuous, the parapet catches the eye; analogously, the Tower of David in 4:4 glitters with the thousand shields of the warriors, that both repel attack and are a splendid ornament. Cedar, however, is strong and dark, associated, as we have seen, with smell and masculinity. The materials are appropriate to their tasks; for in a defensive network walls are visible, doors are concealed (102).

Una vez más, se ve la analogía de los genitales (puerta) como un área oscura, húmeda y olfatoria. Cuando Landy dice, "The body is conspicuous (el palacio de plata), the vagina is secret" (tablas de cedro, 102), hace eco de las palabras de Octavio Paz y Bataille cuando comentan el aspecto animalesco e instintivo de los genitales. Quizá lo que concierne más a estas interpretaciones en cuanto al estudio del poema, es la interpretación de Landy sobre los pechos y la vagina. Estas metáforas parecen enca jar perfectamente con las metáforas extendidas que utiliza Odio a lo largo del poema: 
At puberty, "the day when she shall be spoken for," the body expresses itself by developing breasts, the vagina through the growth of pubic hair, to which the planks of cedar may be compared, as the towers are compared to breasts. Both are powerfully erogenous, the pubic hair through concealing the genitalia, the breasts through announcing their presence. Therein may be discerned the relationship between them: the breasts like the face, make sexuality aesthetic; they refer metonymically to the reticent vagina, that in them expresses itself socially, discreetly ${ }^{11}$.

La interpretación hasta este punto se ha limitado a las imágenes de "muro" y "puerta", o sea, los pechos y la vagina. En el primer caso, la falta de desarrollo, y en el segundo, la protección de ésta. Creo que sería interesante ver los conceptos y las manifestaciones metafóricas desde la perspectiva espacial. A lo largo del poema, se sugieren patrones de imágenes antitéticas: luz y sombra, espacios interiores y exteriores, y lo abierto y lo cerrado. La metáfora del palacio de plata reverbera en el poema en los espacios públicos o exteriores; son espacios con luz. Las tablas de cedro cubren el área interior de sombra; la vagina se describe como "huerto cerrado" (45), "cerrado cauce" (58) y "fuente sellada" (58).

El Círculo Uno o primer canto subtitulado "HABLAN PARA Sí LOS ESPOSOS" expresa mediante un tercio de preguntas retóricas, la incertidumbre de los esposos en cuanto a la acción que deben tomar con la niña prepubescente: “¿Qué haremos / de la niña / que no tiene pechos?" (9-11). A esta primera pregunta, los amados deciden dos acciones: primero, "Le pondremos / dos cielos menores / donde corra el aire / con los ruiseñores" (12-15); y segundo, "Y en los dedos, / largos gajos de tiniebla" (16-17). En el verso 18, la segunda pregunta retórica en forma de anáfora modificada vuelve a intensificar el dilema original y resta credibilidad a la solución recién manifestada mientras

11. Landy, 102-103. 
que alude que el problema no sólo es de ellos sino de la niña misma: "¿Qué hará la doncella, / que no tiene esposo, / ni flores abiertas, / ni nieve pequeña?" (18-21). La falta de pechos como manifestación visible en el cuerpo se expresa como "nieve pequeña". Su imposibilidad física de procrear, atribuida a la pubertad todavía no alcanzada, es descrita como "ni flores abiertas". La tercera pregunta retórica, "¿Y mientras le nacen / los pechos. / Qué haremos / cuando hablaren de ella?" (22-25), recobra su enfoque como problema original de los esposos, y con ella se cierra el primer canto.

El Círculo Dos subtitulado "LA NIÑA; EL PASTOR; EL CORO; LOS ESPOSos" es de carácter expositivo, ya que los esposos, como la niña y el pastor, lamentan la situación y la interpretan como una desgracia. Los esposos reiteran el problema: "Sobre su falda y el vientre, / la noche se abre despacio" (26-27). La vagina es un oscuro espacio interior como lo alude la "noche". El pastor concuerda al decir, "La niña no tiene pechos / y su color por el aire / pone luceros y pájaros" (28-30). El lamento de la niña es la manifestación más desesperante, ya que ella es la afectada. La función emotiva está acrecentada con la expresión patética "Ay", con la cual comienza su parlamento: "Ay, mi cuerpo de oro nuevo, / mi cuerpo de oro en pañales, / Quién lo encontrará en tu huerto, / quién lo llevará a tu casa" (31-34). La serie anafórica aumenta la desesperación. El coro, en función de observador distante y objetivo, comenta: "nadie miraba su cuerpo / de tallo recién cortado" (35-36). El pastor vuelve a comentar la situación, pero se detiene en el aspecto temporal: "Cerca del rocío la niña / tiene los pechos cerrados / y las caderas floridas" (37-39). El "rocío" es la edad en que las niñas suelen alcanzar la pubertad. La mención de "cerca del rocío" da un aire de premura y ayuda como función para incrementar la tensión dramática. El coro, el último en hablar dentro del segundo Círculo, hace eco del infortunio:

Nadie miraba su cuerpo

de tallo recién cortado. 
Solo, sin sueño, sin nadie, insomnio de la azucena para tu huerto cerrado (40-44).

La imagen del cuerpo como "tallo recién cortado", "sin sueño" e "insomnio de la azucena", poetiza la soledad y languidez que debe sentir la niña. La función del coro desde luego lleva la acción a su ápice semántico y emocional, y prepara la transición que le sigue en el tercer Círculo.

El último Círculo del tríptico, titulado "LOS ESPOSOS HACEN LA DEFENSA DE SU HERMANA Y LA OFRECEN", describe como los amados enumeran las cualidades positivas de su hermana. La función del Círculo es proporcionar un equilibrio estructural, disminuyendo la tensión y llevando al lector por el desenlace hacia la conclusión. A través de la técnica de la enumeración metonímica, los esposos describen el cuerpo de la hermana por partes, comenzando con la piel y el muslo:

Su piel tiene la edad de la blancura

y pequeño el color, aligerado,

fino el vientre, y pulido,

entre coral tranquilo y deleitoso, suave el muslo nevado y oloroso, y soledad de luz aprisionada (Esposo, 45-50).

La descripción lírica fluye por la escasez de verbos y por el polisíndeton. Se manifiesta el leitmotiv de la luz y la relación de ésta con los espacios interiores-exteriores. En vez de pechos nevados (que se remite a "palacio de plata" que brilla), su muslo sí es nevado. La luz se concentra en los genitales de la niña. La luz es "brillo por dentro" y se describe como "soledad de luz aprisionada" (50). Hay luminosidad en vez de oscuridad que se esconde detrás de las metafóricas tablas de cedro. La luz, por consiguiente, no es exterior sino interior, y marca una inversión de valores. La esposa entonces describe los 
pechos y añade, "Ah, su pecho, pequeño y retenido, / y mejor que inocente nácar, fugitivo / de aire silvestre por los dulces prados" (5153). El esposo vuelve a dialogar con la esposa y describe la cabeza de la hermana: "De aroma en rama y pasto detenido / mansa la sien, oculta y delicada, / como espuma nocturna entre palomas / tal entre las pastoras nuestra hermana" (54-57). Se debe notar que es la esposa quien describe las partes íntimas de la hermana y no el esposo; de esta forma se constata el comentario hecho por Landy acerca de la voz poética al comienzo de los versículos bíblicos. Usando la técnica turn-taking ${ }^{12}$, ahora es la esposa quien habla de nuevo acerca de la hermana y la que describe en particular, el área genital. Las imágenes son paralelas a las anteriores por el hecho de que describen un espacio interior que no está oscuro sino iluminado: "Cerrado cauce aún, fuente sellada, / abierta al sol si en sombra desdeñada; / mas le haremos cristal donde se peine / y nieve que nevara en su garganta" (58-61). La "sombra desdeñada" se asocia con el subdesarrollo del sistema reproductivo en el plano semántico, pero en cuanto a lo expresivo, remite a la metáfora de las "tablas de cedro". El esposo es el último en hablar y es su voz la que cierra el poema. Es curioso notar que se refiere anafóricamente y en términos estructurales a la primera estrofa bíblica, pero en vez de expresar incertidumbre y preocupación, el esposo es firme en declarar que la hermana es una especie de tesoro resplandeciente que hay que guardar. En vez de "palacio" de plata, será "suave albergue" y "casa" de plata. La inversión de valores es total: en vez de escasez hay plenitud; en vez de sombra hay luz y viceversa:

Si es muro ahí, donde la luz resbala y matinal desciende, y se quebranta, suave albergue será, casa de plata, y si puerta, guarnida y custodiada (62-65).

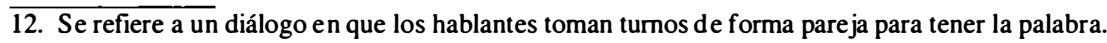


Tanto el cierre como el comienzo del poema sugieren un movimiento de negación o asombro a la afirmación o fantasía. Este movimiento nunca está al alcance del foco poético; la hermanita nunca puede decidirse por sí misma en cuanto a su destino. Aunque está desarrollado en conceptos poéticos, el poema parte estructuralmente del Cantar de Cantares del rey Salomón, y contiene intertextos bíblicos. Bajo esta luz, el poema merece un comentario final.

He mencionado ya que la hermana nunca habla. Su constitución poética y corpórea dependen completamente del discurso de los esposos. Sus preguntas retóricas nunca reciben contestación. Aunque es mi opinión que Odio desarrolla artísticamente un tema bíblico y no encubre un mensaje social crítico, el discurso en sí refleja de manera indirecta un sistema patriarcal cabal ${ }^{13}$, no muy diferente a como operan los sistemas canónicos de literatura en la primera mitad del siglo xx en Centroamérica.

\section{"Para las niñas que siempre están en la luna"}

Este poema publicado en Repertorio Americano ${ }^{14}$ trata las peripecias emocionales y pubescentes de las “niñas". El tono es ligero y a veces cómico puesto que evoca imágenes de la juventud femenina y su preocupación por los asuntos románticos; de ahí, el título. La voz lírica describe a las niñas en lenguaje sensual, construyendo así imágenes relacionadas con la sexualidad latente de "tanta niña". Incluso, en

13. Landy describe el concepto discursivo: "Ella es completamente pasiva: es el enfoque del discurso, no el hablante del mismo. Sin lugar a duda existe una referencia sociológica aquí. El asunto de la voz sexual se formula por el tiempo y por los otros, por el día en el que será pronunciado (énf asis de la autora) en cuanto a ella. La familia la adorna y la manipula, con palacios de plata o tablas de cedro. Lo que es más, la familia hasta participa en su desarrollo físico, idea menos insólita que parece a primeras, si se considera el embellecimiento elaborado de las hijas núbiles en muchas culturas. La familia se apropia del cuerpo como un valor can jeable en la sociedad. La identificación de la Amada con la hermana menor, como imagen de ella misma, lleva a la Amada a su transformación en imagen de sí misma, la imagen que la familia le impone. Ella está casi literalmente bañada en oro, para convertirse en moneda social, adornada con plata y cedro", 104.

14. (22 de febrero de 1947). 
un apóstrofe, la voz lírica les grita, “¡Niñas!” (15), como para sacudirlas de su estupor y hacerles volver a la realidad concreta. Mientras tanto, en su camino, ellas dejan secuelas amorosas entre los muchachitos jóvenes. Odio logra plasmar esta inocencia adolescente mediante una riesgosa conjugación de imágenes eróticas ${ }^{15}$ sin que éstas disminuyan la naturaleza prístina de las niñas. En realidad el arte de la sugestión está magistralmente demostrado en este poema.

En forma antitética, la poeta marca una transición en la octava estrofa al preguntar por las "otras" niñas; no las virginales, sino "las niñas de medio rostro" (18-19) que ya han perdido su flor y que ahora son incompletas. Dada esta exégesis, el tono aparentemente jocoso e inocente al comienzo del poema, ahora se vuelve ambiguo. Quizás la voz lírica quiere advertirles de los peligros amorosos, y por consiguiente, constituye una exhortación a las niñas.

El poema se estructura en doce estrofas de pareados y cuartetos, ambos sin rima alguna. Existe cierta musicalidad debido a la brevedad de los versos, las estrofas y las repeticiones de variados tipos: polisíndeton, epanadiplosis, epímone y epanáfora. La imagen de las niñas con instrumentos musicales, como las gitanas lorquianas, ayuda a la impresión musical. Por consiguiente, se produce una fusión de la parte estructural-mecánica con el concepto semántico.

La primera estrofa introduce la esencia del poema en términos conceptuales y sugerentes:
En el río una niña
come cerezas
suspirando en el aire
su flor entera (1-4).

La sinécdoque "una niña" se remite al título "las niñas" y luego al verso 9: "En el río las niñas". Contra un trasfondo bucólico baquiano,

15. En comparación a otras imágenes eróticas odianas, se podrían calificar éstas como "inocentes" y sugestivas. La combinación compone: niñas, ríos (y arroyos), flores, frutas, aire, suspiros, capricornios y gallos desmayados. 
las adolescentes impregnan el aire con suspiros deleitosos. "Flor" llega a connotar la sexualidad en potencia o la libido. La segunda estrofa describe el efecto que esta escena produce en los "gallitos" o varones jóvenes: "Mientras pasan y pasan / con plumas quedas, / gallitos desmayados / y enredaderas" (1-4). La imagen de la "flor" se amplifica por la perífrasis de los versos 12-15: "derramando en el aire / sus flores nuevas. / Flores con pies desnudos / y vientre alegre".

La transición a la que aludí anteriormente es marcada por la expresión apostrófica “iNiñas!” (15), la cual se amplía en los siguientes dos versos: "Niñas con violoncines / y cascabeles". A partir de aquí, la voz poética se enfoca en las "otras" niñas, en las que no comen cerezas ni las que tienen flor que suspirar sino sombra:

¿Dónde estarán las niñas
de medio rostro,

que enjugan con suspiros

su media sombra?

¿Dónde estarán las niñas

de los arroyos,

las niñas desveladas

de capricornio? (18-25).

Estas niñas han perdido su inocencia y su "flor" y se han vuelto incompletas; han perdido una parte íntegra de su ser. La pregunta retórica en forma de anáfora sugiere la preocupación de la voz lírica por estas niñas y es consciente del peligro que les espera a las que "comen cerezas", "suspiran flores al aire" y las que se desvelan "de capricornio". El concepto zodíaco se interpreta como imagen baquiana de la mitología griega. Bajo esta luz, no sólo es una advertencia sino un lamento. Tal vez el título "Réquiem por las niñas que siempre están en la luna" habría sido más apropiado para este poema. 


\section{"Yo quisiera ser niña""16}

La articulación desganada del deseo de volver a la infancia es el concepto que expresa Odio en este poema. El tono ostenta matices de esperanza pero a la vez es de resignación. La voz lírica vacila entre la añoranza de un pasado ya irrecuperable y la autocrítica en el contexto de una realidad actual ineludible. Más que un regreso a la infancia propiamente dicho, parece ser un lamento por la inocencia y felicidad perdidas, puesto que el presente sólo le ofrece al yo poético tristeza y desamor.

La forma poética consta de 11 estrofas, de versos de longitud irregular y sin rima. Conceptualmente, el poema se puede dividir en dos partes con un verso-estrofa como divisoria que señala el cambio temático y emotivo: "Pero ya, ¿qué he de ser?" (22). Tanto la pregunta retórica (entre otras) como todas las justificaciones o razones en pro y en contra de querer ser niña de nuevo se manifiestan por una variedad de tropos y recursos, el más notorio de los cuales es la repetición. En este caso, las frases y sintagmas señalan condición o posibilidad (“¿Cómo voy a ser ya...?", "si...") para justificar el aparente capricho del deseo.

La primera estrofa anuncia el deseo de la voz lírica: "Yo quisiera ser niña / para acoplar las nubes a distancia / (Claudicadoras altas de la forma)" (1-3). La primera respuesta a la indagatoria, ¿por qué quiere serla?, se contesta en la misma estrofa, pero la voz lírica of rece tres razones más, que aparecen en forma anafórica enumerativa en frase prepositiva adverbial:

Para ir a la alegría por lo pequeño

y preguntar,

como quien no lo sabe

16. Este poema se publicó en Rosario Meza de Padilla, ed., Antología de poetas costarricenses (San José: La Tribuna, 1946) 165-168. 
el color de las hojas

¿Cómo era? (4-8)

La poeta desea recuperar esa sencillez e ignorancia inocente de las cosas. Como adulta, ya ni se acuerda de las cosas aparentemente tan insignificantes como "el color de las hojas" (7) y se las tiene que preguntar. El distanciamiento entre la inocencia de la niñez y la corruptibilidad de las cosas en la vida adulta es vasto, y se aprecia en la siguiente estrofa:

Para ignorar lo verde, el verde mar,

La respuesta salobre del ocaso en retirada, el tímido gotear de los luceros en el muro vecino (9-13).

Es decir, no sólo quiere volver para obtener algo (como indican las primeras dos estrofas), sino que desea olvidar "lo verde". A primera vista, el lenguaje parece críptico y parece desafiar una exégesis confiable, pero la metáfora del "muro" o "muro vecino", patente sello odiano, connota amor o deseos sexuales: el muro que se tiene que vulnerar. La repetición derivativa del color sugiere lo sexual y algo "salobre" que corroe. Las relaciones amorosas como "el tímido gotear de los luceros" es algo que va mermando como el ocaso que se mengua "en retirada".

La cuarta estrofa of rece una razón más por la que la poeta añora el pasado arcádico:

Ser niña

que cayera de pronto

dentro de un tren con ángeles, que llegaban así, de vacaciones a correr un poquito por las uvas, 
o por nocturnos

fugados de otras noches

de geometrías más altas (14-21).

Aunque las imágenes de increíble plasticidad representan un fluir de ideas, más bien son abstracciones de una sola emoción: el retorno a la condición primigenia, no tanto en el aspecto divino, por lo que podrían aludir a las imágenes de los ángeles, sino a ese estado de felicidad pura, quizá prepubescente ${ }^{17}$ y de clara connotación sexual.

"Pero ya, ¿qué he de ser?" (22) marca la transición entre lo que deseaba la voz lírica y su realidad actual. La poeta manifiesta una serie de explicaciones por las cuales el retorno a la inocencia es un sueño pindárico: "Si me han nacido estos ojos tan grandes, / y esos rubios quereres de soslayo" (23-24). La imagen de "ojos grandes" alude a la misma poeta y se confirma en el verso 27: "niña de verdes". La metáfora sin lugar a dudas es ambigua. "Niña de verdes" anafóricamente se remite por igual a "lo verde" y "el verde mar" de la primera parte del poema (vv. 9-10). La naturaleza sexual de la voz poética, de una mujer capaz de amar y que ha amado sin trecho se manifiesta:

Cómo voy a ser ya

esa que quiero yo

niña de verdes,

niña vencida de contemplaciones,

cayendo de sí misma sonrosada,

...si me dolió muchísimo decir

para alcanzar de nuevo la palabra

que se iba,

escapada saeta de mi carne,

17. El poema ostenta una clara referencia autobiográfica que se verá en las estrof as más adelante, por eso me refiero a la poeta que es en este caso, la voz lírica. 
y me ha dolido mucho amar a trechos

impenitente y sola,

y hablar de cosas inacabadas,

finas cosas de niños,

de candor disimulado,

o de simples abejas,

enyugadas a rosarios tristes (25-40).

La repetición sintáctica de sintagmas, un claro rasgo del discurso femenino según Kristeva, se realiza mediante polisíndeton y otras anáforas de forma entrelazada, y se concentra más en la segunda parte del poema después de la marcada transición. La voz lírica, como la de los poetas místicos ${ }^{18}$ ("escapada saeta de mi carne"), lamenta haber amado y haberse abierto emocionalmente al amado, hecho que con razón, la ha dejado vulnerable.

La última estrofa del poema demuestra un claro cinismo por parte de la poeta. Se da cuenta que ya es inalcanzable y hasta "risible" desear volver a la inocencia. Como esto es imposible, igual lo es volver a ser una "niña a la ligera", porque la voz poética pudo amar una vez:

\author{
Cómo voy a ser ya, \\ niña en tumulto, \\ Forma mudable y pura, \\ o simplemente, niña a la ligera, \\ divergente en colores \\ y apta para el adiós \\ a toda hora (43-49).
}

La última imagen de la "niña a la ligera" y sus atributos presenta cierta dificultad hermenéutica, ya que la abstracción puede señalar

18. Referencia a San Juan de la Cruz y Santa Teresa. 
la inocencia o la contundente falta de ésta. En mi opinión, la clave yace en la conjunción adversativa "o". Si en los versos anteriores la "niña en tumulto, / Forma mudable y pura" era aquella niña a la que deseaba regresar la voz lírica, por consiguiente, la "niña a la ligera" es una mujer que ya no es "niña". Debe ser entonces la mujer promiscua y superficial que se ha inmunizado contra el amor. Las imágenes "divergente en colores" y "apta para el adiós / a toda hora" parecen apuntar a esta última interpretación. La poeta ya no puede ser niña inocente ni mujer que anda en picaflor, puesto que ya ha experimentado el amor y sabe lo que significa.

\section{"Suite de la bailarina iluminada"}

Este poema pertenece al libro Territorio del alba y otros poemas $^{19}$. Se incluye en el presente capítulo porque representa un ejemplo del exquisito manejo de metáforas y producción de imágenes que aluden al cuerpo humano. Las descripciones sugestivas de la bailarina, quien aparentemente tiene el poder y la destreza para seducir, se fusionan con imágenes casi surrealistas, y como conjunto, componen una muestra más de la poesía esotérica odiana que raya lo sensualerótico. Una vez más, hay una total ausencia de amante; en su lugar, se poetiza el cuerpo humano y se proyectan imágenes sensuales que apelan a los sentidos.

El poema consta de cinco partes, cada una subtitulada. Su estructura obedece a los patrones esotéricos de las cosmogonías, y de ahí, el significado de algunos de los subtítulos: "Génesis", "Anunciación", "Espera a través de una flauta", "Se inaugura la carne iluminada" y "Razones que tuvo el vacío para inventarla". Aunque el poema es narrativo en esencia, la acción es limitada; en lugar de ésta, abundan las "impresiones" casi fantásticas, muy semejantes a las manifestaciones que caracterizan la poesía "alógica" o dream poetry. El

19. Eunice Odio. Obras completas, ed. Peggy von Mayer (San José: Editorial de la Universidad Nacional-Editorial de la Universidad de Costa Rica, 1996). 
tono del poema es sutil, y da un aire de una suprarrealidad etérea. La característica borrosa se asemeja a una especie de trance que crea la poeta. Esta realidad es emotiva y psicológica. Odio explora en ella, los límites entre la estética artística y los avatares psicológicos. Este poema en particular (y la poesía onírica en general) es representativo de lo que Friedrich comenta en su libro: "man, by virtue of his capacity to dream, is lord of the world" ${ }^{20}$. Como diosa, Odio crea un mundo poético, una impresión estética siguiendo un formato apenas coherente. Para lograrlo, recurre a un sinnúmero de recursos estilísticos, los cuales se verán en más detalle. El poema ostenta claras similitudes con las obras de Jorge Luis Borges, especialmente los cuentos que tratan las cosmogonías y a esa "área gris" entre lo real y lo suprarreal, entre lo despierto y lo soñado, y entre lo concreto y lo líquido. Por otra parte, el tema de la bailarina seductora de gran sexualidad, la que baila entre incienso, se asemeja al poema "Salomé" escrito por el poeta modernista cubano, Julián del Casal. La influencia modernista en general se aprecia en el poema y se manifiesta en el tema exótico y misterioso, en el toque oriental que se logra en el tema de la bailarina que danza entre humo, en las ricas descripciones de los trajes, y en las sinestesias a las que recurre Odio.

El concepto poético es la creación de la bailarina como si fuera un mundo o sistema creado de la nada por la directa intervención divina. Perfectamente plausible es la idea de que la poeta es creadora, y su creación es la bailarina. En un poema como éste, el lector debe tomar el poema sólo como punto de partida, y a través de su imaginación y "lectura", llegar a alguna interpretación. En lo personal, entiendo como tal que la bailarina es la poesía misma: creación exótica y etérea que baila como "una enorme brisa por los árboles" (65), o un conjunto de fragmentos sugestivos que se convierten en el concepto poético mismo.

20. Hugo Friedrich, The Structure of Modern Poetry: From the Mid-Nineteenth to the Mid-Twentieth Centur, trad. Joachim Neugroschel (Evanston: Northwestern UP, 1964) 152. 
“Génesis", la primera estrofa y la más corta de todas, por antonomasia, remite al comienzo de la creación: "La escucha el alto cobre. / Un gran silencio se abre / ordenando los frutos y las islas" (1-3). El "alto cobre" podría ser el cenit o el sol divino que parece responder a deseos ajenos para que aquél cree a la bailarina. El silencio ordena y define, una clara antítesis de la creación bíblica mediante el Verbo o palabra de Dios. El pronombre del complemento directo con el cual comienza el poema alude quizá, a la petición de la poeta o a la creación misma que pide ser creada. El "silencio" que abre y que ordena sugiere que en el principio, sólo había el caos.

El canto siguiente titulado "Anunciación" compone 8 versos de cuatro pareados sin rima. En el plano semántico, el canto contribuye a la tensión dramática y al misterio al que sólo se sugiere y nunca se nombra. Los pronombres directos e indirectos y los adjetivos posesivos aumentan dicho misterio acerca de la identidad de la creación:

Nadie la ha visto, es de oro innumerable,

Le inventan los colores inocentes las estaciones y los coloristas.

Sus tersas venas andan en los anillos de las desposadas.

Sus trajes

en una enorme brisa por los árboles (los destacados son míos, 1-8).

El título "Anunciación" significa que un ser va a venir. Es un ser "de oro innumerable", o sea, más allá de los quilates. Los otros lo forjan: "Le inventan". El misterio se incrementa puesto que los demás no saben lo real del otro por ser invisible hasta ese momento, y 
por ser de carácter "innumerable"21. En incrementos, la voz poética describe los conceptos de la belleza física y la estética plástica del adorno en las "tersas venas" y los "trajes". La imagen de "los anillos de las desposadas" añade a la ambigüedad: ¿es la creación de naturaleza divina, hechura directa sin intervención alguna humana, o es engendrada como señala el verso de los anillos? La poeta sugiere que puede ser (léase "existir") o no ser. Las imágenes de las "desposadas" y de "sus trajes" ("sus" se refiere a la creación y no a las "desposadas") sugieren el aspecto religioso de la unión de la came como acto solemne.

"Espera a través de una flauta" es el tercer canto y funciona como intensificador de la acción. El título alude al baile, éste próximo a iniciarse cuando suena la flauta. El primer verso anuncia que "todo está preparado" (12), lo cual se repite anafóricamente hacia el final de la estrofa. "Todo", como palabra inicial de la estrofa, contribuye a la vaguedad. Igual de ambiguo es la indagatoria ¿preparado para qué? Las respuestas señalan múltiples significados: la creación, la unión o boda o la iniciación de la danza al aparecer la bailarina. También se admite la posibilidad de una fusión de los tres conceptos: la creación de la danza como obra y comunión de los amantes (bailarina y espectador).

Todo está predestinado y listo: "La fuente reclinada alza su sueño, / no desvelado por tan gran silencio" (13-14); "Las rosas organizan el espacio / que han de ocupar su pie, / su blanda altura, / su alegría de marfil sin fondo" (15-18). La poeta crea la imagen de la bailarina comenzando con el pie como en un ascenso vertical; casi parece una diosa. El verso anafórico "todo está preparado" (19) recalca el concepto de comienzo: "Inicia el cielo curvas que se inclinan / conmemorando el aire" (20-21). Lo más notorio de toda esta sección del poema es la imagen de un "despertar". Todo parece listo, casi "congelado" o estático; todo está a punto de iniciar movimiento. $\mathrm{La}$ bailarina va a aparecer en cualquier momento. La "fuente reclinada

21. El cuento borgesiano "Las ruinas circulares" trata el concepto de la creación de un ser que no sabe que sus creadores mismos han sido creados por otro; es una especie de cosmogonía exponencial. 
alza (ascenso vertical) su sueño" y el cielo inicia "curvas que se inclinan". La antítesis ascenso-descenso encapsula a la bailarina que está por aparecer; la imagen evoca el cuadro de Botticelli, "Nacimiento de Venus", en él la diosa Venus aparece entre las aguas, pisando o saliendo de una concha.

El cuarto canto, titulado "Se inaugura la carne iluminada", sugiere una especie de transfiguración, casi de concepto crístico. La que va a aparecer podría tener poderes soteriológicos. Mientras en los cantos anteriores sólo se presiente la bailarina, en éste se concretiza paso por paso. La tensión dramática en el momento de la danza es irrebasable, ya que existe un estado de exaltación:

De súbito,

Un gran otoño de mármol

le inaugura los trajes y la risa.

Entreabren su forma los espejos,

su estatura comienza,

Todo la ve, la escucha,

la presiente en su peso la arboleda;

La sustenta la luz por el aliento,

y por el pie de pasto y el meñique (22-30).

La referencia a mármol y espejos sugiere cierto valor no sólo estético sino divino causado por la luz. La bailarina ahora ha aparecido y es "vista" y "sentida" por todos en reflejos de gran luminosidad. No sólo es idea sino carne "iluminada" con aura. A pesar de que es "carne", no pesa. La imagen es una de etérea liviandad: "la presiente en su peso la arboleda; / La sustenta la luz por el aliento, / y por el pie de pasto y el meñique" (28-30). Más que presencia física, paradójicamente la imagen es emotiva. Los versos 31-32, "El vacío tiene un 
lado / de fina y traspasada levadura", aluden a una emoción que aflora: va de la calma a la apoteosis. La "levadura" es catálisis; la imagen es impactante puesto que no sólo crea, sino que sale de la nada, del "vacío". Odio reúne en esta parte todos los elementos telúricos ${ }^{22}$ para dar completitud artística al acto pseudorreligioso de la transfiguración conceptual. La estructura versal y los espacios indican deliberación y detenimiento. El temor reverencial complementa el aspecto holocáustico de la danza:

Y un color extremoso y de más

las nuevas cabelleras de los ángeles.

La intemperie se atreve

a ser figura de álamo,

Y el humo emprende

su temblor más largo.

En el estanque,

el ruiseñor

se peina

el corazón y el aire (33-42).

La Parte V, titulada "Razones que tuvo el vacío para inventarla", es dedicada a describir a la bailarina como ser ya completo y en su función metapoética ${ }^{23}$. El "vacío" o caos equivale a cosmos, al

22. "luz" (29); "aire", "intemperie" y "aliento" (42, 35, 29); "humo" (léase fuego) (37); "estanque" (léase agua) (39): "arboleda", "pasto" (léase tierra) $(28,30)$.

23. Como posible exégesis, el concepto poético odiano podría equipararse al papel que desempeña la poesía. 
aspecto negativo - por desordenado - de la divinidad. La poeta, dios o la poeta-diosa se une con su creación etérea: "con diurnos menesteres de palomas / que regresa del alba, / la bailarina baila / en la brisa del mundo" (43-46). La idea del regreso se plasma en la imagen de las "palomas" que vuelve a presentarse en clara nota becqueriana ${ }^{24}$ en una expolición en los versos 49-50, "a nube, / en golondrina". La plasticidad de la imagen es extraordinaria, puesto que la poeta fusiona dos imágenes: la crística y la mitológica. El retorno de la bailarina alude al retorno de Cristo al igual que la Venus Andrómeda de Botticelli sobre las aguas:

\author{
En la cintura una isla encadenada \\ y el pie viajando \\ a nube, \\ en golondrina.
}

\title{
La ven llegar de nuevo
}

altos vientos que huían a las olas (47-52).

La imagen de la bailarina que aparece en una verticalidad ascendiente entre humo y aire, y que luego baila, evoca la del poema titulado "Salomé", perteneciente a la colección de sonetos, Mi museo ideal de Julián del Casal. El poeta se apropia del tema al ver un cromo del cuadro de Moreau del mismo título. En el soneto, la voz poética describe el ambiente, la verticalidad de la luz que "cala" el techo y penetra la nave donde hay humo fragante. Al final del soneto, Salomé "emerge" de forma parecida a la bailarina odiana. El erotismo contenido en el soneto casaliano sugiere una mayor sexualidad y se acerca más al tema de la creación que el de Odio.

24. Me refiero al poema LIII, "Volverán las oscuras golondrinas" del Libro de los gorriones, 1871 y cuyo tema es el desengaño amoroso. En el poema becqueriano, las "golondrinas" son los recuerdos y palpitaciones amorosos. En el poema odiano, el retorno de la bailarina se compara por la metáfora de "paloma / que regresa del alba" (43-44); "a nube, / en golondrina" (49-50); y finalmente, "La ven llegar de nuevo" (51). Conceptualmente, los poemas se distinguen entre sí, pero la metáfora de la golondrina como "retorno" está presente en ambos. 
La imagen de la bailarina que se integra a los aires y que va desperdigando alegrías se extiende hasta el final del poema. La voz poética se dirige a la bailarina y explica su raison d'être mediante un apóstrofe:

\section{¡Ay, Señora,} serena y propietaria del viento!

Para que se alegraran el vacío y la amapola las estaciones y los coloristas te inventaron con nombre de planeta delicado,

Y un gran otoño de mármol te inauguró los trajes y la risa que andaban

en una enorme brisa por los árboles (57-65).

La calidad divina de la bailarina como diosa "propietaria" de los elementos, paradójicamente choca con la imagen de un ser creado. Sin embargo, la imagen que perdura al final del poema es la de superioridad desde las alturas, concepto similar a la poesía en general y en específico, a la poesía mágica y creacionista.

\section{"Los elementos terrestres"}

En el extenso poema "Los elementos terrestres"25, el quinto canto titulado "Esterilidad" se integra después de "Canción del esposo a su amada". En la evolución del poema, el concepto ontológico de la esterilidad se presenta a esta conyuntura como la incompletitud del proceso de la creación, y por consiguiente, la negación de la continuidad. Se incluye en este capítulo puesto que su concepto

$\overline{25 . \text { En adelante, }} E T$. 
es antitético a la reproducción y por antonomasia, patentemente integrado a la sexualidad.

La gran soledad que sienten los amados por la hermana estéril se plasma a lo largo de 14 estrofas de gran densidad emotiva y de escasez verbal. La impresión de hondo desconsuelo impregna el canto, pues la procreación es continuidad. Representa el concepto de la reencarnación y la unión con el cosmos a través de la muerte transitoria. Foucault señala la importancia de este concepto para la civilización griega clásica. La dianoeisthai era el término para la presentación de los mejores y más nobles hijos a la ciudad. Como función no sólo biológica sino también social, era grave el impacto psicológico producido por la esterilidad ${ }^{26}$. En el canto odiano, los amados lamentan el estado de la hermana, "en cuya umbral / naufraga el cuerpo de uso eterno" (8-9). Y el tema tiene antecedentes poéticos femeninos en Latinoamérica. El poema se asemeja a "Puertas" de Gabriela Mistral, tanto por su lirismo femenino como por sus términos conceptuales. La puerta ya no como objeto o mero significante, sino transformada y humanizada. Es puerta egoísta que no da hijo; es estéril. Aunque Mistral la toma poéticamente como símbolo del ser humano, el carácter personal e interior de la poeta parece relacionarse con el canto quinto de $E T$.

El tiempo femenino como describe Kristeva es circular en el poema odiano. Sólo hay dos verbos principales y éstos se repiten anafóricamente en los versos 7 y 47: "Así es nuestra hermana". Es una circunstancia que no se puede describir en sintagmas lineares que desarrollan ideas. La esterilidad simplemente representa un gran peso trágico que es muy difícil de comprender. Por esta razón, abundan los símiles, las repeticiones y el polisíndeton como si a través de todos estos tropos, los amados van a comprender la gravedad de la discontinuidad carnal, y por consiguiente, la espiritual de la hermana.

26. Michel Foucault, The Use of Pleasure: Volume 2 of The History of Sexuality (Nueva York: Vintage, 1990) 123. 
Gran parte de las imágenes reflejan el concepto de lo incompleto, lo desunido y fractura: "Tal como flor que sale / y es cortada" (1-2); "escombro de oro en sueños por las ramas" (13); "Asomada al arrimo, / Con media flor y apenas / medio rostro" (18-20). La adjetivación negativa se conjuga en los versos en que se tupen los lamentos: "Sola" $(24,26)$; "Como huella que cae / clara y sin cuerpo" (4142); "Secreto cauce / quieto, / agua sin ruido" (48-50). Las imágenes de "agua" y "flor" alternan con las otras metáforas referentes a la fecundidad y procreación o a la falta de éstas: "instale al humus su unidad primera" (46); "Y con el vientre en que tembló / una piedra" (21-22). Al final del canto, la última estrofa hace eco de la primera en la que la hermana "sale como una flor, y es cortada" (53).

\section{"Esas mujeres perdidas"}

Este poema fue publicado originalmente en Repertorio Americano y lleva una dedicatoria a Nicolás Guillén, gran amigo de la pòeta. De todos los poemas de Odio, "La tapada limeña" es el que más se le asemeja en el tema de la prostitución y la vida que estas personas llevan. Mientras que en "La tapada limeña" se describen las andanzas de la tapada y su "búsqueda", en este poema el foco lírico se concentra en una mujer en particular que está al borde de una muerte violenta. El objeto poético es la prostituta, por consiguiente, todos los puntos referenciales del poema se relacionan indirectamente y por metonimia con el oficio sexual, aunque no existen imágenes ni lenguaje sugestivo. En otras palabras, Odio trata el tema tabú de la prostitución y la respectiva vida insidiosa de las personas involucradas. El tono del poema no es laudatorio ni condenatorio; simplemente describe en lenguaje ambiguo, el hecho próximo de la muerte de la prostituta. anunciado por murmullos igualmente imprecisos. La estructura poética compone 10 estrofas de versos sin rima y de variada longitud. La figura retórica que más se destaca en el poema es la epanáfora: "Señora exacta y sola es" $(5.17,32)$ y "y va a morirse" $(6$, 
27). Esta repetición desempeña una función conceptual puesto que recalca el vaticinio de la muerte que se le aproxima a la mujer. El efecto de crescendo no sólo incrementa la tensión poética sino que concretiza o conjura el suceso fatídico. La estructura también es circular. La voz poética describe la mujer en la actualidad; luego la describe anafóricamente para después revertir el tiempo presente en la parte final del poema.

El expositio ocurre en las primeras cuatro estrofas y asienta las bases para la idea poética que se desenvuelve como historia:

Esa mujer que vimos

pegándose a la luz,

apropiándose los faroles,

con los ojos en veredas caídas,

Señora exacta y sola es,

y va a morirse

en uno de estos días.

Me lo dijo en secreto

aquel señor que se nutre de diminutivos

esclarecidos y esfumados

en las salas de fluoroscopía (1-11).

El poema describe a una mujer nocturna que ambula por la zona roja con toda su luz artificial, un espacio externo. La prostituta, cuyo nombre se desconoce, es descrita a través de un hipérbaton como "Señora exacta y sola es" (5). Aquí el plano morfosintáctico hace eco al elemento semántico. La sintaxis irregular del verso y el hecho que el sintagma anafórico aparece como verso y estrofa aparte, complementan ambos el plano semántico, ya que sugiere ambiguamente que la mujer o es independiente y está hasta cierto punto creída, o puede 
interpretarse como que ya ha sido abandonada y repudiada en su círculo como una especie de mujer de destino "sellado". Este verso, "Señora exacta y sola es", en particular se repite tres veces $(5,17$, 32). La cuarta estrofa narra cierto trasfondo informático que sugiere que la muerte es anteriormente sabida y aceptada como hecho irrevocable. La voz lírica cuenta que se lo dijo en secreto "aquel señor que se nutre de diminutivos / esclarecidos y esfumados / en las salas de fluoroscopía" (9-11). Se sugiere que "aquel señor" es el "padrote", claramente un ser antipático y malquerido por todos, un ser que pasa horas en los lupanares o casinos ("salas de fluoroscopía") iluminados por la luz artificial y comercial. Posiblemente, él será el responsable de la muerte de la mujer.

La voz lírica describe a la prostituta en espacios interiores cuando trabajaba antes dentro del prostíbulo, hecho que en forma de contrapunto alude a la primera estrofa y' los correspondientes espacios exteriores. La mujer, ahora abyecta \ aislada, es recordada en tiempos anteriores a través de imágenes metonímicas:

Yo la había visto ya antes:

cuando solía irse

entre las voces y los cuerpos

de los hombres (12-15).

La epanáfora "Señora exacta y sola de la umbría" (16) se presenta en la sexta estrofa, la cual comienza una serie de tres estrofas sin sintagma verbal principal. Esta ausencia de verbo se presta al lirismo repetitivo que es femenino ! sugerente; las tres estrofas plasman una impresión de la mujer. más que una idea:

Señora exacta y sola de la umbría, limpia de albas presencias. merodeando entre los brazos hondos 
de los prostíbulos, desafiante de coloraciones dudosas,

enlutado de tréboles

su cuerpo todo un gajo

de nocturnas perspectivas,

marchando tras las voces airadas y rugosas

entre predicadoras hierbas

y cacerías displicentes (16-26).

La serie de tropos en forma de sinécdoque ("marchando tras las voces", 24) y prosopopeya ("merodeando entre los brazos hondos I de los prostíbulos", 18-19), dispersos a lo largo de tres estrofas, captan un momento vivido en la vida de la mujer que "[y] ahora va a morirse" (27).

La imagen de esta muerte próxima es perturbadora en toda su poeticidad:

y ahora va a morirse,

decayendo,

tenaz en su morir,

líquido el paso

descontinuado y hosco (27-31).

El morir se describe como "líquido el paso / descontinuado y hosco". Al conocer los hechos referentes a la muerte de la propia poeta, uno no puede evitar pensar en la insólita semejanza entre la muerte de Odio y la muerte descrita en el poema ${ }^{27}$. El paso entre vida

27. Se sabe que el cadáver de Odio fue descubierto en su apartamento de Río Neva en el D.F. después de unos cinco días de muerta. Aparentemente murió mientras se bañaba, y se conjetura que su muerte se debió a un accidente en la tina, hecho que se explica por la ausencia de agua, o a un derrame cerebral, y que pudo con el pie, quitar el tapón de la tina para no ahogarse. El hecho es qui su muerte ocurrió entre líquidos. 
y muerte a veces se describe en términos licuescentes, como una franja crepuscular donde ya no hay vida ni muerte. Los griegos compartían este concepto de la relación entre agua y muerte. Ésta se manifestaba en la imagen del río Styx o laguna Aqueronte, donde Caronte llevaba a las almas en una barca de una ribera a otra. En este sentido, la imagen del río se representa como continuo y fluido. Por otra parte, el uso que le da la poeta como "paso líquido" y a la vez "paso descontinuado" presenta una paradoja. Lo que fluye es, lógicamente continuo, en todo su valor semántico; "descontinuado" es lo que cesa de ser. La imagen es ambigua. Según Bataille ${ }^{28}$, el paso a la muerte es continuidad o unión con el todo; en otras palabras, la muerte es vida, como ya se ha visto en capítulos anteriores.

El poema concluye, entonces, con los dos versos anafóricos que señalan su circularidad y se cierra con la imagen de la mujer y su destino implacable: "Señora exacta y sola. / Limpia de albas presencias" (32-33).

\section{"De noche, por esas noches por esos muros"}

"De noche", poema publicado póstumamente según Von Mayer, es de clásica hechura odiana en cuanto a las imágenes evocadas. El poema en sí es breve; apenas contiene 13 versos en 4 estrofas. Lo que se pierde en comprensión sintáctica, el poema lo recobra en la sugestión a través de las etéreas metáforas telúricas y siderales. El tono evoca cierta emoción de magnitud o reverencia. Parece una electrizante sensualidad en potencia. La sintaxis surge fragmentada debido principalmente al hipérbaton, pero la esencia sexual permanece, mientras que se desvanecen las palabras.

La primera estrofa, "De noche, / con la estrella, / se ve muy alto el muro vecino" (1-3), evoca la romántica noción de noche, lo sideral y la imagen de "muro". En la obra odiana, suelen aparecer juntas las

28. Georges Bataille, Death and Sensuality: A Study of Eroticism and the Taboo (Nueva York: Amo, 1977). 
imágenes de objetos sólidos (torre, muelle, muro) con elementos líquidos (río, aguas) y telúricos (luna, la estrella, lucero). En esta conjugación de elementos sensuales, suelen aparecer las imágenes de la noche, flores y pájaros. Esta combinación parece integrar la receta odiana para un elíxir mágico "a lo baudelaireano" para conjurar sugestivos mundos sexuales. Para poder apreciar el impacto total del breve poema y más importante aun, apreciar la sintaxis violada por el hipérbaton, reproduzco aquí el poema en su totalidad:

De noche, con la estrella, se ve muy alto el muro vecino

Sobre el mundo, y hasta parecen muelles en sus aguas gastadas,

y hasta hay niños que purgan una pena de alondra,

De noche con la estrella hay corazones de hombre que oscilan sobre el muro (1-13).

La imagen del muro proyecta solidez como la figura de la torre o el muelle en aguas, pero en el caso particular de este poema, el muro es la defensa femenina que protege la flor y su integridad contra el hombre que pretende vulnerarla. Los elementos masculinos son los muelles en el agua que llevan al muro, y desde la perspectiva masculina, parece muy alto, sin embargo, la tenacidad varonil como, "hay corazones de hombre / que oscilan / sobre el muro", es un hecho $\mathrm{y}$ asegura que dicho acontecer nocturno se va a repetir. 
En este estudio hemos visto cómo Eunice Odio ha logrado plasmar el tema de la sexualidad y sus matices ocultos en espacios públi$\cos$. La variedad de poemas que se incluye aquí es una muestra contundente de la capacidad privilegiada de la poeta por crear espacios dialógicos entre ella y el público, temas cuyos límites muchas veces no son claros. Es loable la fusión magistral del elemento estético con el psicológico y ontológico sin sacrificar el arte y rebajarse a la "erótica" inmunda. Díez Borque comenta que "serían pornográficas, en sentido negativo, las poesías que se sirvieran del lenguaje como vehículo para producir imaginaciones lúbricas sustitutivas. Pero ya quedó dicho que se puede alcanzar una altura estética - para ésta reservo el término poesía erótica" (43). Odio no rehúye, sin embargo, la palabra; más bien la maneja de forma extraordinariamente magistral para lograr y conservar el concepto poético. En esto yace la gran habilidad estética. En fin, la poeta pudo expresar inquietudes humanas cotidianas basándose en imágenes que vacilan entre livianas sugestiones y luminosos remolinos lingüísticos, cuyas mareas son capaces de succionar al lector e introducirlo en su mundo poético. 